\title{
NUCLEOLAR SUPPRESSION, ITS INHERITANCE AND ASSOCIATION WITH TAXONOMY AND SEX IN THE GENUS RIBES
}

\author{
ELIZABETH KEEP \\ Fruit Breeding Section, East Malling Research Station
}

Received 27.vii.70

\section{InTRODUGTION}

NAVAShin (1928) used the word " amphiplasty" to denote morphological changes occurring in chromosomes following interspecific hybridisation. Changes affecting individual chromosomes of the complement were termed "differential amphiplasty", and this phenomenon, involving the consistent disappearance of the satellite of one of the parental nucleolar chromosomes, was described in species hybrids of Crepis in a series of papers by Navashin and his co-workers and others (Navashin, 1927, 1928, 1934; Babcock and Navashin, 1930; Avery, 1930; Hollingshead, 1930). Interspecies hybrids of several other genera have since been found to show a similar differential amphiplasty, notably Salix (Wilkinson, 1941, 1944, Solanum (Yeh and Peloquin, 1965) and Ribes (Keep, 1960, 1962a, 1965; Tun, 1960, 1961). In Crepis, differential amphiplasty is not associated with sterility (Navashin, 1934) or phylogeny, and it occurs equally in reciprocal crosses; it is as marked in polyploids as in diploids (Babcock and Navashin, 1930). In polyploid hybrids involving Ribes nigrum L. (black currant) and $R$. grossularia L. (gooseberry) differential amphiplasty is less marked than in the diploid $F_{1}$, the normally "suppressed " black currant satellite being evident in some cells. The satellite of the $R$. nigrum nucleolar chromosome reappears on segregation, as does that of Crepis (Navashin, 1934; Keep, 1962a).

In Salix (Wilkinson, 1944) and in black currant $\times$ gooseberry hybrids (Keep, 1962a) the number of satellites at metaphase and number of nucleoli per cell at late telophase in hybrids showing amphiplasty are identical. However, in interphase cells of black currant $\times$ gooseberry hybrids, one or more small nucleoli up to the number of black currant satellite chromosomes present may occur, indicating a reduced capacity to form nucleoli later in the cell division cycle. For convenience, the term " nucleolar suppression " will be used to cover all degrees of inequality in nucleolar formation by parent satellite chromosomes, as assessed on relative nucleolar size and/or number in hybrids. Further data on interspecies hybrids of Ribes, showing an association between the degree of nucleolar suppression and taxonomy, evidence bearing on the inheritance of nucleolar suppression and the occurrence of sex-associated nucleolar size differences in the dioecious species $R$. orientale Desf., are reported in this paper.

\section{Materials AND MEthods}

A number of species hybrids raised or acquired for the furtherance of the Ribes breeding programme at East Malling were classified into four 
nucleolar "suppression grades" following microscopic examination of root-tip nucleoli stained in aceto-carmine (Keep, 1962a). In grading, since the relative sizes of interphase nucleoli sometimes varied considerably

TABLE 1

Nucleolar suppression in Ribes species hybrids

\begin{tabular}{|c|c|c|c|c|c|}
\hline \multirow{2}{*}{$\begin{array}{l}\text { Subgenus and } \\
\text { section of } \\
\text { parents }\end{array}$} & \multirow[b]{2}{*}{ Parentage } & \multicolumn{4}{|c|}{ "suppression grade" } \\
\hline & & $" 3 "$ & " $2 "$ & "1" & $\stackrel{" 0}{ }$, \\
\hline \multirow{2}{*}{$R_{5} \times R_{5}$} & $R$. nigrum $\times R$. dikuscha & - & - & 2 & 一 \\
\hline & $R$. nigrum $\times R$. bracteosum & & & 2 & - \\
\hline \multirow[t]{13}{*}{$H_{1} \times H_{1}$} & $R$. grossularia $\times R$. alpestre & - & - & 1 & 3 \\
\hline & $R$. grossularia $\times R$. burejense & 一 & - & 1 & - \\
\hline & $R$. grossularia $\times R$. cynosbati & - & - & 1 & - \\
\hline & $R$. grossularia $\times R$. grossularioides & - & 一 & - & 2 \\
\hline & $R$. grossularia $\times R$. inerme & - & 1 & 1 & - \\
\hline & $R$. grossularia $\times R$. leptanthum & - & 1 & - & - \\
\hline & $R$. grossularia $\times R$. niveum & - & 1 & - & - \\
\hline & $R$. grossularia $\times R$. non-scriptum & - & - & 2 & - \\
\hline & $R$. grossularia $\times R$. oxyacanthoides & - & - & 3 & - \\
\hline & $R$. grossularia $\times R$. parishii & - & - & - & 1 \\
\hline & $R$. grossularia $\times R$. pinetorum & - & - & 1 & - \\
\hline & $R$. grossularia $\times R$. stenocarpum & - & 1 & - & - \\
\hline & $R$. grossularia $\times R$. watsonianum & - & 1 & 1 & - \\
\hline Totals & Intrasectional hybrids & 0 & 5 & 15 & 6 \\
\hline$R_{5} \times R_{2}$ & R. nigrum $\times R$. aureum & - & - & 1 & - \\
\hline \multirow[t]{3}{*}{$R_{5} \times R_{3}$} & $R$. nigrum $\times R$. glutinosum albidum & 1 & - & - & - \\
\hline & $R$. nigrum $\times R$. sanguineum & - & 1 & - & - \\
\hline & $R$. sanguineum $\times R$. nigrum & 1 & - & - & - \\
\hline$R_{5} \times R_{4}$ & $R$. nigrum $\times R$. cereum & 4 & - & - & - \\
\hline$R_{5} \times R_{7}$ & $R$. nigrum $\times R$. longeracemosum & - & - & 1 & - \\
\hline Totals & Intrasubgeneric hybrids & 6 & 1 & 2 & 0 \\
\hline \multirow[t]{3}{*}{$R_{5} \times H_{1}$} & $R$. nigrum $\times R$. grossularia & 5 & - & - & - \\
\hline & $R$. grossularia $\times R$. nigrum & 2 & - & - & - \\
\hline & $R$. nigrum $\times R$. divaricatum & 2 & - & - & - \\
\hline$B_{1} \times R_{5}$ & $R$. orientale $\times R$. nigrum & 1 & 1 & - & - \\
\hline$H_{1} \times R_{3}$ & $R$. grossularia $\times R$. sanguineum & - & 1 & - & - \\
\hline$B_{1} \times H_{1}$ & $R$. orientale $\times R$. grossularia & 5 & - & - & - \\
\hline \multirow[t]{2}{*}{ Totals } & Intersubgeneric hybrids & 15 & 2 & 0 & 0 \\
\hline & $\begin{array}{l}\text { ggenus Berisia Spach., Section Eu } \\
\text { penus Grossularia Rich., Section } \\
\text { ggenus Ribesia Berl., Section Syn } \\
\text { ggenus Ribesia Berl., Section Cal } \\
\text { ggenus Ribesia Berl., Section Cer } \\
\text { ogenus Ribesia Berl., Section Eu } \\
\text { ggenus Ribesia Berl., Section Rib }\end{array}$ & $\begin{array}{l}\text { risia Ja } \\
\text { ugrossu } \\
\text { hocalyx } \\
\text { otrya S } \\
\text { hyllum } \\
\text { eosma }\end{array}$ & $\begin{array}{l}\text { cz. } \\
\text { aria Ens } \\
\text { Berl. } \\
\text { ach. } \\
\text { pach. } \\
\text { ancz. }\end{array}$ & & \\
\hline
\end{tabular}

from cell to cell, approximately five cells from each of four or five root tips were examined per plant. Grade " 0 " indicates that nucleoli appeared approximately equal in all cells examined; grade " 1 " indicates a slight but noticeable size difference in some cells but that in many others the 
nucleoli appeared equal; grade " 2 " denotes a size difference, sometimes marked, in a majority of cells; and grade " 3 " indicates marked nucleolar suppression in all cells, cells with two nucleoli sometimes being rare in this class. On this system, several black currant and gooseberry cultivars have been graded " 0 " or " 1 ".

To obtain a more accurate picture of nucleolar suppression in certain progenies, camera lucida drawings were made, at a magnification of $\times 3160$ on heavy Croxley Script paper, of interphase nucleoli of five comparable cells from each of four root tips per plant. Each drawing was carefully cut out and weighed to $0.1 \mathrm{mg}$. on a Townson and Mercer torsion balance. It was considered that the weights so obtained would provide an adequate measure of relative nucleolar sizes.

\section{NUGleolar SUPPRESSION AND TAXONOMY}

The "suppression" grades of 52 hybrid plants, representing 25 different species combinations and grouped according to the taxonomic classification of their parents (Rehder, 1954), are included in table 1.

Average suppression grades for intrasectional, intrasubgeneric and intersubgeneric hybrids were $0.96,2 \cdot 44$ and 2.88 respectively, strongly suggesting an association between the extent of nucleolar suppression and degree of parental differentiation.

\section{INHERITANGE OF NUGLEOLAR SUPPRESSION}

Three small back-cross progenies derived from crossing interspecific hybrids graded " 3 " for nucleolar suppression to black currants were graded on relative sizes of root tip nucleoli as already described.

TABLE 2

Nucleolar suppression in first back-cross progenies

\begin{tabular}{|c|c|c|c|c|c|c|}
\hline \multirow[b]{2}{*}{ Family } & \multirow[b]{2}{*}{ Parentage } & \multicolumn{5}{|c|}{$\begin{array}{l}\text { No. of seedlings } \\
\text { suppression grade }\end{array}$} \\
\hline & & $" 4 "$ & "3" & " $2 "$ & “1” & $" 0 "$ \\
\hline B902 & $\begin{array}{l}\times \mathrm{B}-1 \quad R . \text { "carrierei" }(R . \text { nigrum } \times R . \\
\text { glutinosum albidum }) \times R . \text { nigrum }\end{array}$ & - & 6 & 2 & 5 & - \\
\hline B905 & $(R$. nigrum $\times R$. cereum $) \times R$. nigrum & 一 & 2 & 一 & 3 & 一 \\
\hline B1111 & $R$. nigrum $\times(R$. nigrum $\times R$. sanguinem $)$ & 2 & 12 & 15 & 10 & - \\
\hline
\end{tabular}

Segregation in both progenies, $\mathrm{B} 902$ and B905, in which the $\mathrm{F}_{1}$ hybrids were the seed parents, appeared to be discontinuous, with approximately equal peaks at grades " 3 " and " 1 ". Although numbers are far too small to be conclusive this suggests that in these progenies nucleolar suppression was segregating more or less as a unit and was probably under major gene control. In Family B1111, however, in which $R$. nigrum was the seed parent, segregation for nucleolar suppression appeared to be more or less continuous, with a peak at grade " 2 ". Two exceptional seedlings in which only one and three cells out of five and six root tips, respectively 
contained two nucleoli (which were very unequal), were graded " 4 ", and represented a more marked nucleolar suppression than their $F_{1}$ parent.

To obtain a more accurate picture of nucleolar suppression in this progeny, weights of nucleolar drawings were obtained as already described. The mean ratios per cell per plant of weight-of-larger/weight-of-smaller nucleolus (nucleolar suppression ratio, NSR) are shown in fig. l. The results in general are similar to those obtained by eye grading (table 2), there being a marked peak around NSRs of 1.5 to 2.5 (grades " 1 " and " 2 ") and a long " tail" of 11 seedlings (grade " 3 ") showing increasingly marked nucleolar suppression. The two seedlings graded " 4 " in table 2 are not represented in fig. 1 .

Within plants in Family Bllll, nucleolar sizes were often markedly variable, standard errors per plant for the larger nucleolus in a cell ranging from 0.091 to 0.860 , for the smaller from 0.059 to 0.541 , and for the NSR from 0.052 to 4.200 . There was no correlation between NSRs and standard errors for large or for small nucleoli, but in general, means and standard errors per plant of NSRs increased in parallel. Thus, plants with NSRs of $10.87,10.04,7.23,6.49$ and 5.99 had standard errors of $3.79,4.20,1 \cdot 81$, 1.91 and 2.45 respectively, while plants with NSRs of 3.08, 2.06, 1.69 and 1.26 had standard errors of $0.48,0 \cdot 15,0.19$ and 0.09 respectively.

\section{Nugleolar size AND SEX IN $R$. orientale Desf.}

Inspection of shoot and root-tip squashes from a male and female accession, respectively, of $R$. orientale showed that the two nucleoli in interphase cells of the female were usually approximately equal in size whereas those of the male were markedly unequal. Examination of root-tip squashes of five female and eight male seedlings from crossing these two accessions showed that the male plants again had greater size differences between their nucleoli than the females, although this difference was less marked in some plants than in the male parent.

To obtain a more accurate estimate of relative nucleolar sizes, root tips were taken from comparable clonally propagated material of four female and five male seedlings and of their female parent. Camera lucida drawings of nucleoli were made at a magnification of $\times 3040$, cut out and weighed as already described.

The average ratio weight-of-larger/weight-of-smaller nucleolus per cell in the five male plants was 1.570 , with a range of 1.285 to 1.773 ; that of the females was $1 \cdot 276$, with a range of $1 \cdot 163$ to $1 \cdot 359$. Although one of the male plants (not included in the initial examination) came within the female range of ratios, an analysis of variance showed that the males as a group had significantly higher $(\mathrm{P}<0.05)$ ratios than the females; there was also significant $(\mathrm{P}<0.01)$ variation within each sex. The average ratios for four of these plants (two male and two female) which had been included in the initial examination were 1.773 and 1.585 , and 1.182 and 1.308 respectively. Clearly, examination without actual measurement is adequate to classify into two groups based on differences of this magnitude. Thus, a total of ten male and seven female seedlings in the $F_{1}$ progeny were found to differ consistently according to sex in nucleolar size ratios, with one atypical male plant showing a ratio within the female range. 


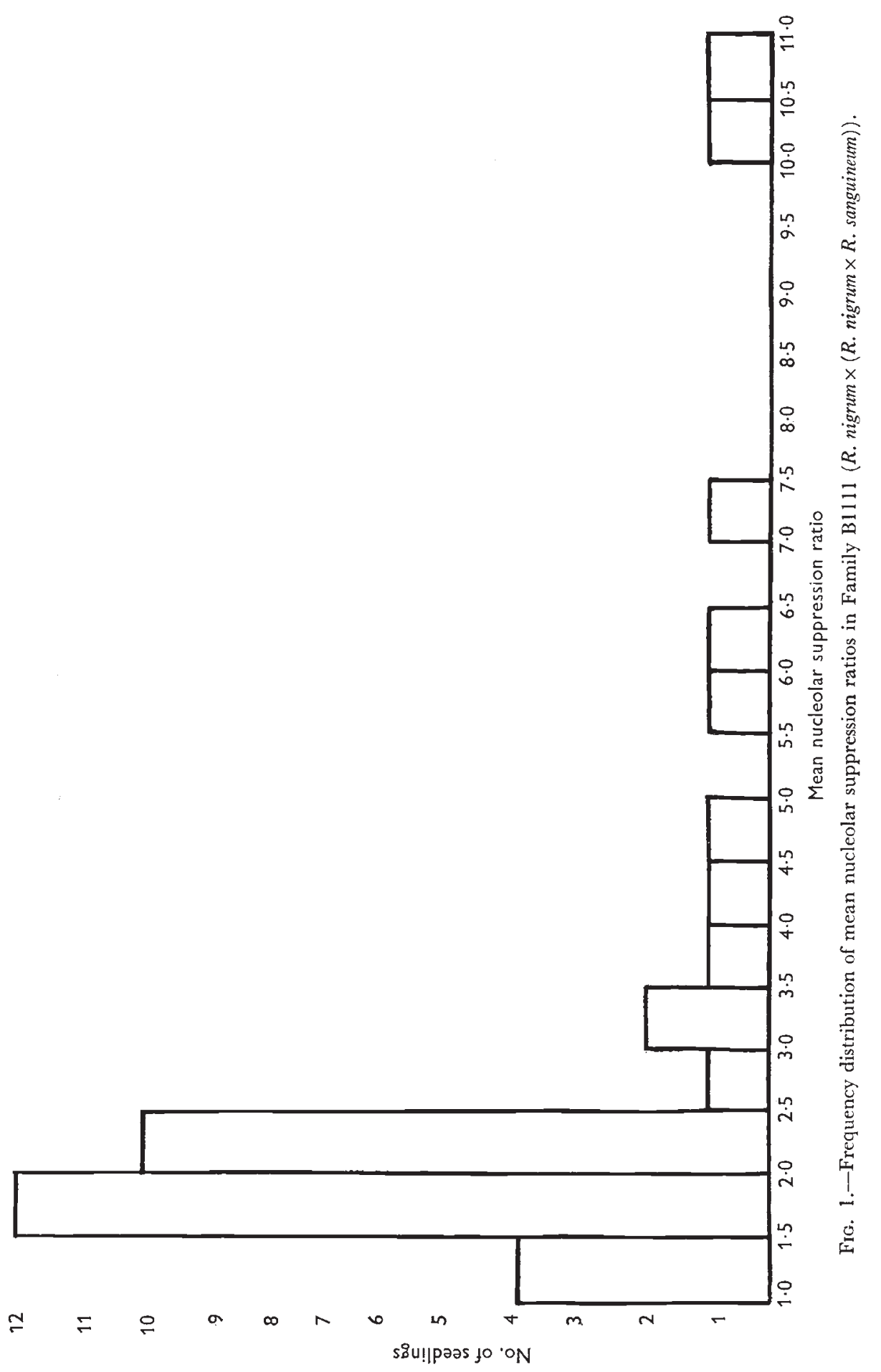




\section{Discussion}

Although the taxonomic relationships of Ribes species reflect rather accurately the degree of fertility shown by their $F_{1}$ hybrids (Nilsson, 1955; Keep, 1962b), and "distant" hybrids appear to be those most likely to show nucleolar suppression (table 1), this phenomenon in Ribes as in Crepis (Navashin, 1934) is not necessarily associated with sterility. Thus, hybrids of $R$. nigrum with $R$. glutinosum albidum, $R$. sanguineum and $R$. cereum graded " 2 " or " 3 " for nucleolar suppression (table 1 ), are all sufficiently fertile to back-cross to $R$. nigrum. On the other hand, the totally sterile hybrid $R$. nigrum $\times R$. longeracemosum shows very little nucleolar suppression (grade " 1 "). Nevertheless, no fully fertile Ribes hybrid showing marked nucleolar suppression has yet been found.

Keep (1962a) noted that in the Ribes hybrids then under investigation plant vigour did not appear to be affected by the much reduced functioning of one of the parental nucleolar organisers. Similarly, in the $F_{1}$ hybrids described in this paper and in segregating back-cross progenies, vigour is not associated with full functioning of both organisers. This fact is of interest in the light of present theories on nucleolar function. The increasing evidence that nucleoli are involved in ribosomal RNA (rRNA) synthesis has been summarised by, amongst others, McConkey and Hopkins (1964) and Perry (1967). This evidence would suggest that the rRNA and possibly protein (Perry, 1967) of the ribosomes in hybrids showing marked nucleolar suppression is formed very largely in the nucleolus of the nonsuppressed parent. In first back-cross hybrids, this means that approximately 75 per cent. of recurrent parent chromatin can collaborate effectively with ribosomes whose rRNA is manufactured mostly in the nucleolus of the donor parent. This suggests either that rRNA specificities are of little importance in general protein synthesis, or else that, at least in genera in which nucleolar suppression is widespread, the rRNAs of different species are similar. In this connection, Matsuda and Siegel (1967) showed that rRNAs from four plant species of four different families were remarkably similar to each other in hybridisation behaviour with several different plant DNAs.

The assumption that nucleolar suppression indicates the presence of the donor parent's nucleolar organiser only, is not justified on present evidence, and further work on later back-cross generations will be needed to determine if, in fact, the alien organiser is also the sole suppressing agent. The wide spread in NSRs in Family Bllll (fig. 1) suggests that other factors can have a considerable modifying effect. In this progeny, the recurrent parent, $R$. nigrum, was the female, in contrast to Families B902 and B905, in which the $\mathrm{F}_{1}$ parent was the female and in which there appeared to be a sharper division into suppressed and non-suppressed seedlings (table 2). The preponderance of seedlings showing little nucleolar suppression in Bl111 may be due to the presence of pure black currant apomicts which cannot be distinguished with certainty from hybrids; the majority of seedlings were, however, certainly true hybrids.

The association of a higher nucleolar suppression ratio with maleness in $R$. orientale suggests that the nucleolar chromosome may be involved in some way in sex differentiation. The occurrence of one male plant out of 11 with a ratio in the female range may indicate crossing over between a male- 
determining gene and the nucleolar organiser; further investigations are needed to determine the frequency of such exceptional male plants. The frequency with which nucleolar chromosomes are also sex chromosomes in insects and bryophytes was pointed out by Gates (1939). Similarly, the nucleolar chromosome is thought to be the sex chromosome in a number of higher plants such as Ginkgo biloba (Lee, 1954; Pollock, 1957), Cycas pectinata (Abraham and Mathew, 1962), Spinacia oleracea (Dressler, 1958), Coccinia indica (Bhaduri and Bose, 1947) and Asparagus officinalis (Thuesen, 1960). In some of these species sex differences are associated with the presence or absence of a satellite or the number and size of nucleoli. Thus, in Ginkgo biloba, Pollock (1957) found four satellited chromosomes and two, three or four nucleoli in resting nuclei of female trees, and only three satellited chromosomes and one, two or three nucleoli in resting nuclei of male trees. Ho (1963) was unable to confirm Pollock's findings, although sex differences in satellite number were described by Lee (1954); possibly karyologically distinct races of Ginkgo exist. In Cycas pectinata the male has only one satellited chromosome (Abraham and Mathew, 1962), while in one strain of Spinacia oleracea (Dressler, 1958) the Y chromosome of male plants bears a satellite in addition to the secondary constriction found also in the $\mathrm{X}$. The $\mathrm{Y}_{2}$ chromosome, but not the $\mathrm{X}$, of one race of Rumex hastatulus is satellited (Smith, 1969). In young pollen grains of Cannabis sativa, the average nucleolar volume of XX (monoecious) plants was 130 per cent. compared with the 100 per cent. of XY (male) plants, and the frequency distribution of nucleolar volumes for male plants showed a tendency towards a double peak, whereas XX types showed only a single peak (Herich, 1961).

Jensen (1940) pointed out that nearly all reported cases of sex chromosomes in plants relate to species which are members of genera which also contain monoecious or hermaphrodite species, suggesting a recent origin for the unisexual condition; also many species with "apparent" sex chromosomes show evidence of recent hybrid origin in their meiotic behaviour. In discussing the origin of dioecy in plants, Darlington (1937) and Lewis (1942) suggested that the genes primarily determining sex must be associated sooner or later with a structural change such as an inversion. This would suppress crossing-over, which is a necessary condition for the accumulation of groups of sex-differentiating genes. The inverted region of the chromosome would develop into the differential segment. It seems probable that differential amphiplasty in species hybrids, in which the satellite thread of the nucleolar chromosome remains condensed, might prove an effective barrier to crossing-over within the nucleolar organiser region. In the first back-cross Family B902 ( $R$. glutinosum albidum $\times R$. nigrum $^{2}$ ), not only did segregation for nucleolar suppression occur (table 2 ) but also eight out of ten seedlings which reached the flowering stage failed to produce pollen, although all seedlings tested proved female fertile, and the remaining two showed 92 per cent. and 56 per cent. of apparently viable pollen respectively. Although Lewis (1942) does not consider gynodioecy to be a transitional stage in the development of dioecy, gynodioecy has not been reported in Ribes species, whereas all of the numerous species of the subgenus Berisia are dioecious. In the case of Family B902 absence of pollen was not invariably associated with presence or absence of nucleolar suppression, but such hybridisation between hermaphrodites in nature, resulting at once in male sterility and, probably, a barrier to 
crossing-over in a segment of the nucleolar chromosome, might well lead to the ultimate establishment of full dioecy, the sexes being differentiated, perhaps, by relative nucleolar volumes. The genus Salix may represent a later stage in the evolution of dioecy following hybridisation. Jensen (1940) disagrees with the normal classification of Salix as a strictly dioecious genus, since numerous instances of perfect flowers and all gradations between this state and monoecy and dioecy occur, and considers the genus is not yet fully sexually stabilised. It is probably significant that in a genus in which all species are more or less dioecious, all interspecific hybrids investigated have shown differential amphiplasty, and the species themselves show evidence of a hybrid origin also involving amphiplasty (Wilkinson, 1944).

Pazourkova (1964) and Kuznetsova et al. (1966) report the presence of sex chromatin in male $\left(\mathrm{XY}_{1} \mathrm{Y}_{2}\right.$, Kihara and Ono, 1925) plants of Rumex acetosa, as does Zuk (1969) in male plants of $R$. thyrsiflorus, and Pazourkova found "nuclear bodies" in leaves of Ginkgo biloba and roots of Melandrium album (XX female, XY male, Blackburn, 1923; Winge, 1923) which could correspond to sex chromatin, although they were not confined to one sex. Choudhuri (1969) showed that the DNA replication sequence in sex chromosomes of $M$. album was similar to that of mammalian sex chromosomes, one arm of the $\mathrm{X}$ chromosome in the female and part of the $\mathrm{Y}$ being late replicating. In Rumex thyrsiflorus, both heterochromatic Y chromosomes, but not the euchromatic X, are late replicating (Zuk, 1969). Sex chromatin has not yet been seen in dioecious Ribes species, nor heteropycnotic bodies in species hybrids showing differential amphiplasty. However, an analogy could perhaps be drawn between the suppression of nucleolar function in species hybrids and the inactivation of one, or part of one, of the $\mathrm{X}$ chromosomes in mammals (Lyon, 1961, 1962). Although normally random inactivation of the paternal or maternal $\mathrm{X}$ occurs in man and mouse, Hamerton et al. (1969) showed that in the female mule (horse $\times$ donkey), the paternal $\mathrm{X}$ preferentially shows late labelling and is presumably also preferentially inactivated, since the product of the paternally derived glucose-6-phosphate dehydrogenase allele, which is X-linked, is only weakly represented. This makes the parallel between behaviour of sex and of nucleolar chromosomes even closer: consistent inactivation of the same (or part of the same) $\mathrm{X}$ chromosome in a female hybrid mammal and of the same parental nucleolar organiser in some plant hybrids; the presence of a differential segment in sex chromosomes and of a condensed satellite thread in plant hybrids; and dosage compensation in certain $\mathrm{X}$-linked genes (data summarised by Thompson, 1965) and sometimes in production of nucleolar material (McClintock, 1934; Beerman, 1960; Longwell and Svihla, 1960; Brown and Gurdon, 1964).

\section{SUMmary}

1. Marked differences in the mean sizes of the two interphase nucleoli of root-tip cells were observed in 29 out of 52 interspecific Ribes hybrids. This size inequality, considered to be due to the partial suppression of the nucleolar organising capacity of one of the parental satellite chromosomes, tended to increase with increasing parental differentiation.

2. Three back-cross progenies of which $R$. nigrum was the recurrent parent, segregated for nucleolar suppression, a range from little or no 
suppression to suppression equal to or exceeding that found in the $F_{1}$ parents being observed.

3. In a progeny of the dioecious species $R$. orientale, the mean ratio per cell of larger/smaller nucleolus was significantly higher in male plants than in females.

4. The frequency with which nucleolar chromosomes are also sex chromosomes in insects, bryophytes and higher plants is discussed. It is suggested that nucleolar suppression in interspecific hybrids may be one pathway to the establishment of dioecy.

Acknowledgments. - I wish to thank Mr D. A. Holland for carrying out the statistical analyses and Mrs S. L. Butler for excellent technical assistance.

\section{REFERENGES}

Abraham, A., AND mathew, P. M. 1962. Cytological studies in the Cycads: sex chromosomes in Cycas. Ann. Bot., 26, 261-266.

AvEry, P. 1930. Cytological studies of five interspecific hybrids of Crepis leontodontoides. Univ. Calif. Publs agric. Sci., 6, 135-167.

BabCOCK, E. B., AND NaVAShin, M. 1930. The genus Crepis. Bibliographia genetica, 6, 1-90.

BEERMAN, w. 1960. The nucleolus as an important living component of the cell nucleus. Chromosoma, 11, 269-296.

BHADURI, P. N., AND BOSE, P. C. 1947. Cytogenetical investigations in some common cucurbits, with special reference to fragmentation of chromosomes as a physical basis of speciation. 7. Genet., 48, 237-256.

BlAGKBURN, к. в. 1923. Sex chromosomes in plants. Nature, Lond., 112, 687-688.

BROWN, D. D., AND GURDON, J. B. 1964. Absence of ribosomal RNA synthesis in the anucleolate mutant of Xenopus laevis. Proc. natn. Acad. Sci. U.S.A., 51, 139-146.

GHOUDhURI, H. C. 1969. Late DNA replication pattern in sex chromosomes of Melandrium. Can. F. Genet. Cytol., 11, 192-198.

Darlington, C. D. 1937. Recent Advances in Cytology. 2nd Edition, Churchill, London.

DRESSLER, O. 1958. Cytogenetical investigations on diploid and polyploid spinach

(Spinacia oleracea L.) with special consideration of the inheritance of sex as the basis of inbred-heterosis breeding. Z. PfZ̈̈ucht., 40, 385-424.

Gates, R. R. 1939. Nucleoli, satellites and sex chromosomes. Nature, Lond., 144, 794-795.

hamerton, J. L., GianNelli, F., COllins, F., hallett, J., Fryer, A., MCGUire, V. M., AND SHORT, R. v. 1969. Non-random X-inactivation in the female mule. Nature, Lond., 222, 1277-1278.

HERICH, R. 1961. Nucleole and sex differentiation. Caryologia, 14, 375-381.

но, т. 1963. The nucleolar chromosomes of the maidenhair tree. F. Hered., 54, 67-74.

hOllingsheAd, L. 1930. Cytological investigation of hybrids and hybrid derivatives of Crepis capillaris and Crepis tectorum. Univ. Calif. Publs agric. Sci., 6, 55-94.

JENSEN, H. w. 1940. On the questionable existence of sex chromosomes in the angiosperms. Am. Nat., 74, 67-88.

KEEP, E. 1960. Amphiplasty in Ribes. Nature, Lond., 188, 339.

KEEP, E. 1962a. Satellite and nucleolar number in hybrids between Ribes nigrum and R. grossularia and in their backcrosses. Can. F. Genet. Cytol., 4, 206-218.

KEEP, E. 1962b. Interspecific hybridisation in Ribes. Genetica, 33, 1-23.

KEEP, E. 1965. Cytological notes. II. Ribes. Rep. E. Malling Res. Stn for 1964, $104-107$.

KiHARA, h., AND ONO, T. 1925. The sex-chromosomes of Rumex acetosa. Z. indukt. Abstamm.-u VererbLehre, 39, 1-7.

kuznetsova, v. G., AND POlJakova, T. F. 1966. Sex chromatin in Rumex acetosa L. Genetika, Moskva, 9, 164-169.

LEE, C. L. 1954. Sex chromosome in Ginkgo biloba. Am. F. Bot., 41, 545-550.

LEWIS, D. 1942. The evolution of sex in flowering plants. Biol. Rev., 17, 46-67.

LONGWELL, A. C., AND SVIHLA, G. 1960. Specific chromosomal control of the nucleolus and of the cytoplasm in wheat. Expl Cell Res., 20, 294-312.

Lyon, M. 1961. Gene action in the X-chromosome of the mouse (Mus musculus L.). Nature, Lond., 190, 372-373. 
LYON, M. 1962. Sex chromatin and gene action in the mammalian X-chromosome. $A m$. 7. hum. Genet., 14, 135-148.

MATSUDA, K., AND SIEGEL, A. 1967. Hybridisation of plant ribosomal RNA to DNA: the isolation of a DNA component rich in ribosomal RNA cistrons. Proc. natn. Acad. Sci. U.S.A., 58, 673-680.

MCCLINTOCK, в. 1934. The relation of particular chromosomal elements to development of the nucleoli in Zea mays. Z. Zellforsch. mikrosk. Anat., 21, 294-328.

MCCONKEY, E. H., AND HOPKINS, J. W. 1964. The relationship of the nucleolus to the synthesis of ribosomal RNA in HeLa cells. Proc. natn. Acad. Sci. U.S.A., 51, 1197-1204.

Navashin, M. 1927. Changes in the number and form of chromosomes as a result of hybridisation. Z. Zellforsch. mikrosk. Anat., 6, 195-233.

Navashin, M. 1928. Amphiplasty, a new caryological phenomenon. Z. indukt. Abstamm.-u VererbLehre, Suppl. 2, 1148-1152.

Navashin, M. 1934. Chromosome alterations caused by hybridisation and their bearing upon certain general genetic problems. Cytologia, 5, 169-203.

NiLsson, F. 1955. Amphidiploid species in the genus Ribes. Rep. 14th int. hort. Congr., Scheveningen, 697-711.

pazourkova, z. 1964. Sex chromatin in Rumex acetosa L. Preslia, 36, 422-424.

Perry, R. P. 1967. The nucleolus and the synthesis of ribosomes. Prog. nucleic Acid Res. and mol. Biol., 6, 219-257.

POLlOCK, в. G. 1957. The sex chromosomes of the maidenhair tree. F. Hered., 48, 290-294.

REHDER, A. 1954. Manual of Cultivated Trees and Shrubs. 996 pp. MacMillan and Co., Toronto.

SмrтH, в. w. 1969. Evolution of sex-determining mechanisms in Rumex. Chromosomes Today, 2, 172-182.

тномpson, м. w. 1965. Genetic implications of heteropyknosis of the X-chromosome. Can. F. Genet. Cytol., 4, 202-213.

thuesen, A. 1960. Cytogenetical studies in Asparagus officinalis. Asskr. K. Vet. Landbohøjsk., 47-71.

Tun, N. N. 1960. Cytological investigations. Rep. Scott. hort. Res. Inst., 7, 44-45.

Tun, N. N. 1961. Cytological investigations. Rep. Scott. hort. Res. Inst., 8, 49.

wilkinson, J. 1941. The cytology of the cricket bat willow. Ann. Bot., 5, 149-165.

wilkinson, J. 1944. The cytology of Salix in relation to its taxonomy. Ann. Bot., 8, 269-284.

WINGE, $\oslash$. 1923. On sex chromosomes, sex determination and preponderance of females in some dioecious plants. C.r. Trav. Lab. Carlsberg, 15, 1-26.

YEH, B. P., AND PELOQUIN, s. J. 1965. The nucleolus associated chromosome of Solanum species and hybrids. Am. F. Bot., 52, 626.

źuK, J. 1969. Autoradiographic studies in Rumex with special reference to sex chromosomes. Chromosomes Today, 2, 183-188. 